\title{
Survey and Identification of Fusarium Wilt Disease in Chilli (Capsicum annuum L.)
}

\author{
A. Thoyajakshi Bai ${ }^{1 *}$, Ch. Ruth ${ }^{1}$, K. Gopal ${ }^{1}$, K. Arunodhayam ${ }^{1}$, \\ B. Tanuja Priya ${ }^{2}$ and M. Ramakrishna ${ }^{2}$
}

${ }^{1}$ Department of Plant Pathology, College of Horticulture, ${ }^{2}$ Department of Horticulture, College of Horticulture, Dr. Y. S. R. Horticultural University, Anantharaju peta, Y. S.R Kadapa, Andhra Pradesh-516105, India

*Corresponding author

\begin{tabular}{|c|c|}
\hline & A B S T R A C T \\
\hline & \multirow{5}{*}{$\begin{array}{l}\text { Chilli (Capsicum annum L.) is an important vegetable cum spice crop grown in Andhra } \\
\text { Pradesh. Fusarium wilt emerged as one of the major disease of chilli. Survey was } \\
\text { conducted in major chilli growing areas and identified the wilt pathogen. In this } \\
\text { investigation, among the } 27 \text { locations surveyed in Andhra Pradesh, the highest disease } \\
\text { incidence was recorded from E. Thandrapaadu }(40 \%) \text { of kurnoolmandal of Kurnool } \\
\text { district followed by Byluppala }(34 \%) \text { in Gonegandlamanadal and Remata }(30.03 \%) \text { of } \\
\text { kurnoolmandal and the lowest disease incidence recorded in Hanumapuram }(8 \%) \text { of } \\
\text { yemmiganurmandal. In Kadapa district, the disease incidence varied from } 6.00 \%-24.00 \% \text {. } \\
\text { Narjampalli of Mylavarammandal }(12.60 \%) \text { showed maximum disease incidence while } \\
\text { Vemaguntlapalli of Jammalamadugumandal showed minimum disease incidence }(1.87 \%) \text {. } \\
\text { The disease incidence in other locations were comparatively low. In Guntur district, the } \\
\text { disease incidence ranged from 0.00- } 8.00 \% \text {. The highest disease incidence was recorded } \\
\text { from Nandigama of Sattenapallimandal (8\%) and no disease incidence was recorded from } \\
\text { Dharanikota and Piduguralla villages The Fusarium wilt disease was observed to be high } \\
\text { during November-December months. }\end{array}$} \\
\hline $\begin{array}{l}\text { Chilli wilt, Survey, } \\
\text { Fusarium }\end{array}$ & \\
\hline Article Info & \\
\hline $\begin{array}{l}\text { Accepted: } \\
06 \text { May } 2018 \\
\text { Available Onli } \\
10 \text { June } 2018\end{array}$ & \\
\hline & \\
\hline
\end{tabular}

\section{Introduction}

In India Chilli occupies an area of 840 thousand hectares with an annual production of 2096M.tonnes (2016-17). The incidence of wilt varied from 0.0 to 75.0 percent in different states of India (Anonymous, 2005). Andhra Pradesh (A.P.), Karnataka, Tamil Nadu, Maharashtra are major chilli growing states in India which together contributes about $75 \%$ of total cultivated area. Though India is the leading producer, the average yield of chilli is very low (1.11 t/ha dry chilli) as compared to developed countries like USA, China etc, where the average yield ranges from 3-4 t/ha. The popularity and demand for chilli are providing a boost to the chilli industry, but in the recent years, the production and productivity is constrained due to many biotic and abiotic stresses. However, 
Chilli is attacked by a large number of pathogens, out of them Fusarium oxysporum causing vascular wilt is the most predominant and causes 10-50 per cent crop losses around the world and 10-80 per cent in India.

\section{Materials and Methods}

Collection, isolation and identification of Fusarium pathogen from major chilli growing areas

The survey conducted during rabi season. Different locations from three districts viz., Kurnool, Kadapa and Guntur were chosen for the survey. Diseased plant samples were collected randomly from the farmer's fields from different locations of the above stated districts of A.P. In each district three mandals and in each mandal, three villages were surveyed for the wilt disease.

In each field row, each 10 meters long were selected randomly. A total of 27 different locations in 3 districts of A.P. were covered. In each row, total number of plants and number of diseased plants were counted and expressed in terms of percentage.

The plants showing symptoms of Fusarium wilt such as yellowing and wilting in younger leaflets, epinasty, stunting and yellowing of older leaves, brown vascular discoloration of the collar portion of plants were identified and recorded. Per cent disease incidence was assessed by counting the number of affected plants out of the total plants. The percent disease incidence will be recorded based on formula.

PDI = total no. of infected plants /total no. of plants observed x 100

The representative samples of infected plants were collected for isolation and identification of pathogens for further studies.

\section{Isolation of pathogens from infected plants}

Diseased chilli plants showing typical symptoms of wilt were collected from different locations of the above stated districts of A.P. The pathogen Fusarium oxysporum causing wilt in chilli was isolated by tissue segment method from the freshly infected collar portion of the plant. Freshly infected chilli stem and collar region were washed thoroughly with distilled water. A small portion of diseased tissues along with a portion of adjacent healthy tissue were cut into small pieces (3 to $5 \mathrm{~mm}$ in length) and then surface sterilized with one per cent sodium hypochlorite solution for one minute.

The pieces then were rinsed thrice with sterilized distilled water. The surface sterilized and rinsed pieces were inoculated aseptically on sterilized petriplate containing PDA medium supplemented with streptomycin sulphate to prevent bacterial contamination. The inoculated petriplates were incubated at $25 \pm 2{ }^{\circ} \mathrm{C}$ for five to six days. When the fungal colony developed, a small bit of single mycelium is transferred on another petriplate containing PDA medium to obtain pure culture. The pure cultures of the pathogen were maintained in PDA slants for further studies. The cultural and morphological characters of the isolates were also studied.

\section{Pathogenicity}

Pathogenecity test was carried out using a root dip inoculation method. Seedlings of chilli were uprooted gently from the nursery. The roots of seedlings were dipped in a spore suspension of $F$. oxysporum broth containing $10^{6}$ spores per $\mathrm{ml}$ for $5 \mathrm{~min}$, dried briefly on a tissue paper and then two seedlings were transplanted into the pots. Four replications were maintained, plants were irrigated regularly. The disease incidence was calculated twenty days after transplanting. 


\section{Results and Discussion}

\section{Incidence of Fusarium wilt disease in Andhra Pradesh during 2017-18}

The initial symptoms of Fusarium wilt were noticed at flowering to fruiting stage in Kadapa district and the first incidence of the disease was recorded during octoberNovember where initial fruiting stage begins.

The data revealed that, among the 27 locations surveyed in Andhra Pradesh, the highest disease incidence was recorded from $\mathrm{E}$. Thandrapaadu $(40 \%)$ of kurnoolmandal of Kurnool district followed by Byluppala (34\%) in Gonegandlamanadal and Remata (30.03\%) of kurnoolmandal (Fig. 1 and 2). The lowest disease incidence was recorded in Hanumapuram $(8 \%)$ of Yemmiganurmandal. In Kadapa, the disease incidence varied from 6.00\%-24.00\% (Table 1).

Narjampalli of Mylavarammandal (12.60\%) showed maximum disease incidence while Vemaguntlapalli of Jammalamadugumandal showed minimum disease incidence (1.87\%). The disease incidence in other locations were comparatively low. The Fusarium wilt disease was observed to be high during NovemberDecember.

In Guntur district, the disease incidence ranged from $0.00-8.00 \%$. The highest disease incidence was recorded from Nandigama of Sattenapallimandal $(8.00 \%)$ and no disease incidence was recorded from Dharanikotaand Piduguralla villages.

The details of cultivation practices of the crop, followed by farmers were collected with the objective of understanding the disease incidence, which in turn will help in managing the disease to certain extent. One of the major differences observed in cultivation practices is the use of the raised bed system adapted in
Guntur, where comparatively less disease incidence was observed. Where as in Kurnool and Kadapa also some farmers followed raised bed system but majority are of ridge and furrow system. In ridge and furrow system, flooding type irrigation tends to high chances of wilt infection irrespective of the season. During the survey period, the high soil moisture and very high temperature was observed in Kurnool district, which became favourable condition for the wilt disease occurrence. The farmers belonging to $\mathrm{E}$. Thandrapadu and villages of Gonegandlamandal of Kurnool district have raised chilli crop year by year in the same region, without following crop rotation practice and thereby high disease incidence was recorded. Whereas continuous rainfall over one month (during entire September) has led to water stagnation and high soil moisture resulting in increased incidence of fusarium wilt in Kadapa district. The mean average of fusarium wilt recorded highest in Kurnool district $(24.56 \%)$ followed by Kadapa (14.341\%) and Guntur districts (3.465\%) shown in figure 3 .

Wani et al., (2014) conducted an extensive field survey in five major vegetable growing areas of district Anantnagand Kulgam of Kashmir valley (temperate region of India) and found that Fusarium wiltdisease was can occur in nursery during transplantation but the maximum wilt incidence can be noticed duringflowering/fruiting stage.

F. oxysporum was reported to cause not only wilting and fruit rot but also reduced plant growth rate and yield in chilli (Vidhyasekaran and Thiagarajan, 1981).

Singh et al., (1998), studied that Fusarium wilt, became more serious in chilli growing tracts of India, particularly in Karnataka in black cotton soil leading up to 25 per cent yield loss (Madhukar and Naik, 2004). 
Table.1 Details of locations and per cent disease incidence (PDI) fusarium wilt in Chilli in Andhra Pradesh during 2017-18

\begin{tabular}{|c|c|c|c|c|c|}
\hline \multirow{2}{*}{$\begin{array}{l}\text { District } \\
\text { in A.P. }\end{array}$} & \multirow{2}{*}{$\begin{array}{c}\text { Time of } \\
\text { Collection }\end{array}$} & \multicolumn{2}{|c|}{ Location } & \multirow[t]{2}{*}{ PDI* } & \multirow{2}{*}{$\begin{array}{l}\text { Longitude \& } \\
\text { Latitude }\end{array}$} \\
\hline & & Mandal & Village & & \\
\hline \multirow[t]{10}{*}{ Kadapa } & \multirow[t]{9}{*}{ Oct, 2017} & \multirow[t]{3}{*}{ Mylavaram } & Narjampalle & $\begin{array}{c}24.00 \\
(29.33)\end{array}$ & $14^{\prime} 53 \mathrm{~N}, 78^{\prime} 01 \mathrm{E}$, \\
\hline & & & Thorrivemula & $\begin{array}{c}18.00 \\
(25.10)\end{array}$ & $14.90 \mathrm{~N}, 78^{\prime} 32 \mathrm{E}$, \\
\hline & & & Peddakamerla & $\begin{array}{c}10.00 \\
(18.44)\end{array}$ & $14.72 \mathrm{~N}, 78.31 \mathrm{E}$ \\
\hline & & \multirow[t]{3}{*}{ Jammalamadugu } & P. Bommepalli & $\begin{array}{l}16.00 \\
(23.58)\end{array}$ & $14.85 \mathrm{~N}, 78.21 \mathrm{E}$ \\
\hline & & & Kothaguntlapalli & $\begin{array}{c}20.00 \\
(26.56)\end{array}$ & $14.79 \mathrm{~N}, 78.23 \mathrm{E}$ \\
\hline & & & Vemaguntlapalli & $\begin{array}{c}6.00 \\
(14.18)\end{array}$ & $14.82 \mathrm{~N}, 78.27 \mathrm{E}$ \\
\hline & & \multirow[t]{3}{*}{ Peddamudiyam } & Konda sunkesula & $\begin{array}{l}15.03 \\
(22.95)\end{array}$ & $15.05 \mathrm{~N}, 78.30 \mathrm{E}$ \\
\hline & & & Diguvakaluvatala & $\begin{array}{c}8.00 \\
(16.43)\end{array}$ & $15.03 \mathrm{~N}, 78.24 \mathrm{E}$ \\
\hline & & & Papaya palli & $\begin{array}{c}12.04 \\
(20.53)\end{array}$ & $15.20 \mathrm{~N}, 78.35 \mathrm{E}$ \\
\hline & & Mean & & $(14.341)$ & \\
\hline
\end{tabular}

\begin{tabular}{|c|c|c|c|c|c|}
\hline \multirow{2}{*}{$\begin{array}{c}\text { District in } \\
\text { A.P. }\end{array}$} & \multirow{2}{*}{$\begin{array}{l}\text { Time of } \\
\text { Collection }\end{array}$} & \multicolumn{2}{|c|}{ Location } & \multirow[t]{2}{*}{ PDI* } & \multirow{2}{*}{$\begin{array}{l}\text { Longitude \& } \\
\text { Latitude }\end{array}$} \\
\hline & & Mandal & Village & & \\
\hline \multirow[t]{10}{*}{ Kurnool } & \multirow[t]{9}{*}{ Nov, 2017} & \multirow[t]{3}{*}{ Gonegandla } & Byluppala & $\begin{array}{r}34.00 \\
(35.67)\end{array}$ & $15.63 \mathrm{~N}, 77.50 \mathrm{E}$ \\
\hline & & & Errabadu & $\begin{array}{c}20.00 \\
(26.56)\end{array}$ & $15.67 \mathrm{~N}, 77.65 \mathrm{E}$ \\
\hline & & & Gonegandla & $\begin{array}{r}28.00 \\
(31.90)\end{array}$ & $15.75 \mathrm{~N}, 77.59 \mathrm{E}$ \\
\hline & & \multirow[t]{3}{*}{ Kurnool } & E.Thandrapadu & $\begin{array}{r}40.00 \\
(39.23)\end{array}$ & $15.83 \mathrm{~N}, 78.17 \mathrm{E}$ \\
\hline & & & G.Singavaram & $\begin{array}{r}25.03 \\
(33.14)\end{array}$ & $16.88 \mathrm{~N}, 81.65 \mathrm{E}$ \\
\hline & & & Remata & $\begin{array}{c}30.03 \\
(33.34)\end{array}$ & $15.83 \mathrm{~N}, 77.85 \mathrm{E}$ \\
\hline & & \multirow[t]{3}{*}{ Yemmiganuru } & Hanumapuram & $\begin{array}{c}8.00 \\
(16.43)\end{array}$ & $15.67 \mathrm{~N}, 80.05 \mathrm{E}$ \\
\hline & & & H.Muravani & $\begin{array}{r}15.03 \\
(23.03)\end{array}$ & $15.74 \mathrm{~N}, 77.35 \mathrm{E}$ \\
\hline & & & Doddimekala & $\begin{array}{r}21.03 \\
(27.42)\end{array}$ & $15.73 \mathrm{~N}, 77.46 \mathrm{E}$ \\
\hline & & Mean & & .56 & \\
\hline
\end{tabular}




\begin{tabular}{|c|c|c|c|c|c|}
\hline \multirow[t]{9}{*}{ Guntur } & \multirow[t]{9}{*}{ Nov, 2017} & \multirow[t]{3}{*}{ Amaravathi } & Dharanikota & $\begin{array}{c}0.00 \\
(0)\end{array}$ & $16.57 \mathrm{~N}, 80.35 \mathrm{E}$ \\
\hline & & & Mutyapalem & $\begin{array}{c}3.03 \\
(10.31)\end{array}$ & $15.87 \mathrm{~N}, 80.48 \mathrm{E}$ \\
\hline & & & Jidugu & $\begin{array}{c}5.00 \\
(12.92)\end{array}$ & $16.34 \mathrm{~N}, 80.17 \mathrm{E}$ \\
\hline & & \multirow[t]{3}{*}{ Sattenapalli } & Nandigama & $\begin{array}{c}8.00 \\
(16.43)\end{array}$ & $16.77 \mathrm{~N}, 80.28 \mathrm{E}$ \\
\hline & & & Gudipudi & $\begin{array}{c}6.03 \\
(14.54)\end{array}$ & $16.42 \mathrm{~N}, 80.21 \mathrm{E}$ \\
\hline & & & Peddamakkena & $\begin{array}{c}4.05 \\
(12.25)\end{array}$ & $16.43 \mathrm{~N}, 80.24 \mathrm{E}$ \\
\hline & & \multirow[t]{3}{*}{ piduguralla } & Guthikota & $\begin{array}{r}2.05 \\
(9.10)\end{array}$ & $16.43 \mathrm{~N}, 80.25 \mathrm{E}$ \\
\hline & & & Piduguralla & $\begin{array}{c}0.00 \\
(0)\end{array}$ & $16.48 \mathrm{~N}, 79.89 \mathrm{E}$ \\
\hline & & & Vemulacheruvu & $\begin{array}{l}3.03 \\
(33.40)\end{array}$ & $16.47 \mathrm{~N}, 80.30 \mathrm{E}$ \\
\hline & & & Mean & 3.465 & \\
\hline
\end{tabular}

Fig.1 Survey of chilli infected fields in E. thandrapadu Fig.2 Survey in Remata village of Kurnool district
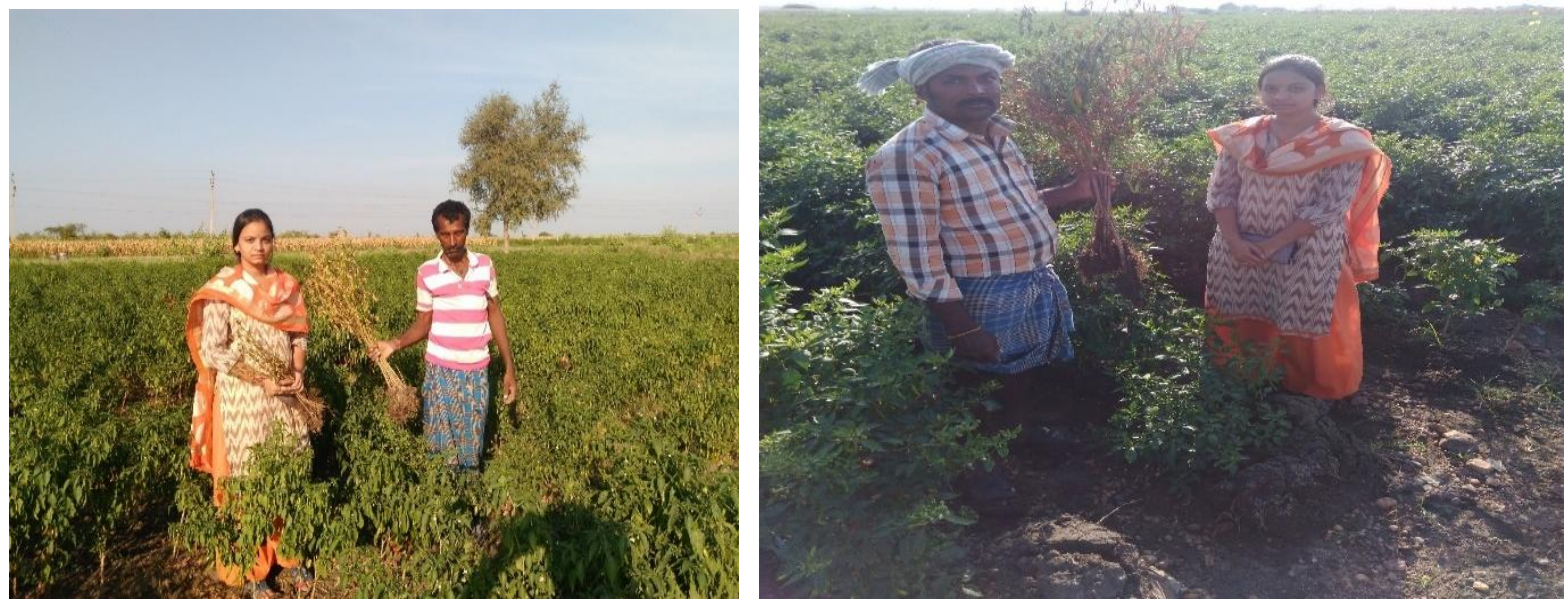
Fig.3 The mean averages of Fusarium wilt incidence from different districts surveyed in Andhra Pradesh

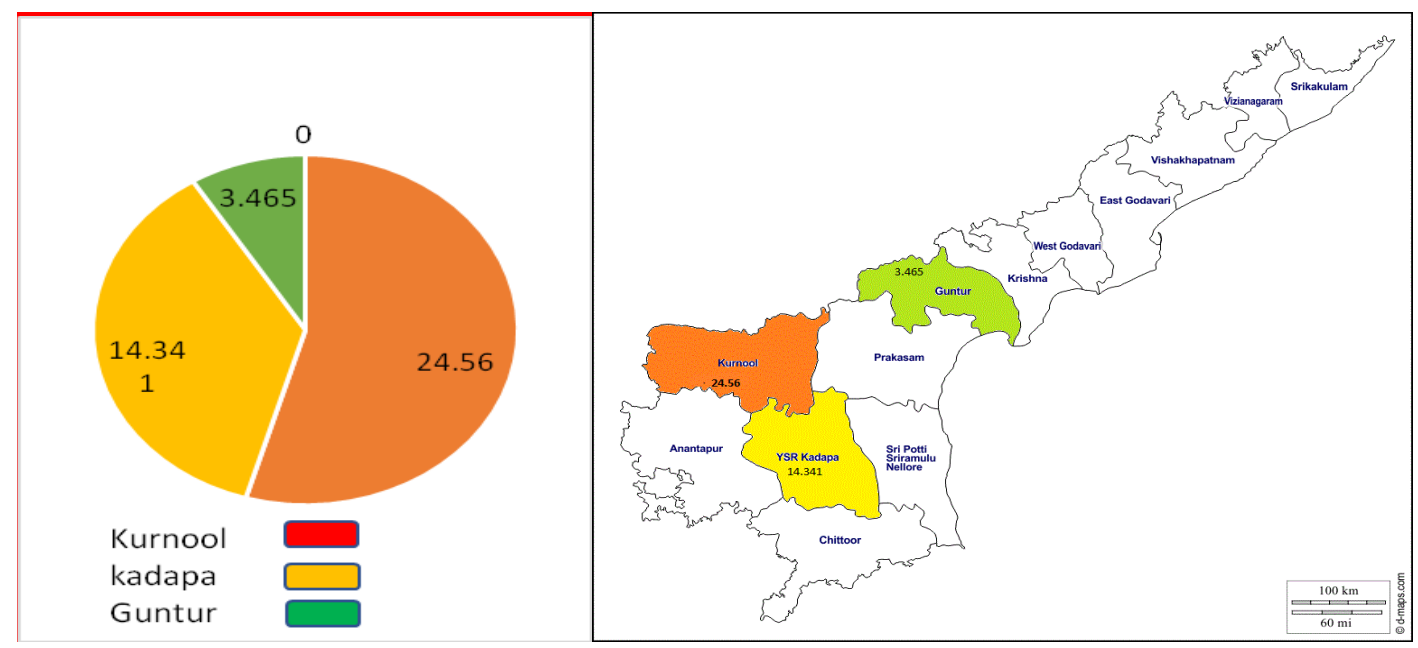

\section{Identification of the pathogen}

The isolated pathogens were sent for N.C.F.T (National Centre of Fungal Taxonomy) for the morphological identification of the wilt pathogen, the result confirmed the pathogen is Fusarium oxysporum (NCFT, 081.17) and one strain as Fusarium solani (NCFT, 086.17).

Fusarium wilt is one of the a most destructive soil borne disease in chilli, throughout the A.P. as it constrains the production of the crop, there is a need for farmers to implement integrated approach for the qualitative control of the disease.

\section{References}

Abhishek Mishra, VedRatan, Subha Trivedi, Dabbas, Kripa Shankar, Singh, A.K., Supriy a Dixit and Yatindra Srivastava. 2018. Survey of anthracnose and wilt of chilli: A potential threat to chilli crop in central Uttar Pradesh. Journal of
Pharmacognosy and Phytochemistry. 7(2): 1970-1976.

Anonymous. 2005. Network project on wilt of crops submitted to ICAR. Annual Report, New Delhi, 7.

Madhukar, H.M. and Naik, M.K. 2004. Evaluation of bioagents against Fusarium wilt of chilli (Capsicum annuum). In: Proc. 15th Int. Plant Protection Towards 21st Century held in Beijing, China, 540. 7

Singh, A., Singh A.K and Singh, A.1998. Screening of chilli germplasms against Fusarium wilt. Crop Research. 15:132133.

Vidyasekharan, P. and Thiagarajan, C. 1981. P. seed borne transimission of Fusarium oxysporum in chilli, Indian phytopathology.34, 211

Wani, S.A., Mohidin, F.A., Hamid, B., Baba, Z.A., Paddar, S.A. and Bhat, M.A. 2014. Incidence of Fusarium wilt of chilli (Capsicum annuum L.) in Kashmir valley and its management by Trichoderma spp. Mycopath. 12(1): 1-8.

\section{How to cite this article:}

Thoyajakshi Bai, A., Ch. Ruth, K. Gopal, K. Arunodhayam, B. Tanuja Priya and Ramakrishna, M. 2018. Survey and Identification of Fusarium Wilt Disease in Chilli (Capsicum annuum L.). Int.J.Curr.Microbiol.App.Sci. 7(06): 1073-1078. doi: https://doi.org/10.20546/ijcmas.2018.706.127 